\title{
Introgressed Saltol QTL Lines Improves the Salinity Tolerance in Rice at Seedling Stage
}

\author{
S. L. Krishnamurthy ${ }^{1 *}$, Preeti Pundir ${ }^{1}$, Arvinder Singh Warraich ${ }^{1}$, Suman Rathor ${ }^{1}$, \\ B. M. Lokeshkumar ${ }^{1}$, Nagendra Kumar Singh ${ }^{2}$ and Parbodh Chander Sharma ${ }^{1 *}$ \\ ${ }^{1}$ Division of Crop Improvement, ICAR-Central Soil Salinity Research Institute, Karnal, India, ${ }^{2}$ Rice Genomics Laboratory, \\ ICAR-National Institute for Plant Biotechnology, New Delhi, India
}

OPEN ACCESS

Edited by:

Jayakumar Bose,

University of Adelaide, Australia

Reviewed by:

Aladdin Hamwieh,

International Center for Agricultural Research in the Dry Areas (ICARDA),

Syria

Kalenahalli Yogendra,

University of Adelaide, Australia

${ }^{*}$ Correspondence:

S. L. Krishnamurthy krishnagene@gmail.com Parbodh Chander Sharma pcsharma.knl@gmail.com

Specialty section:

This article was submitted to Plant Breeding, a section of the journal Frontiers in Plant Science

Received: 09 October 2019 Accepted: 25 May 2020

Published: 11 June 2020

Citation:

Krishnamurthy SL, Pundir $P$, Warraich AS, Rathor $S$, Lokeshkumar BM, Singh NK and Sharma PC (2020) Introgressed Saltol

QTL Lines Improves the Salinity Tolerance in Rice at Seedling Stage.

Front. Plant Sci. 11:833.

doi: 10.3389/fpls.2020.00833
Rice is a staple food crop in Asia and plays a crucial role in the economy of this region. However, production of rice and its cultivating areas are under constant threat of soil salinity. A major QTL, Saltol, responsible for salinity tolerance at seedling stage has been mapped on chromosome 1 using Pokkali/IR29 Recombinant Inbred Lines (RIL) population. The present study was aimed to incorporate Saltol Quantitative Trait Loci (QTL) in two high yielding mega rice varieties i.e. Pusa44 and Sarjoo52 through Marker Assisted Backcross Breeding (MABB). To improve the seedling stage salinity tolerance in these cultivars, we introgressed the Saltol QTL from donor parent FL478 a derivative of Pokkali. A total of three backcrosses $\left(\mathrm{BC}_{3}\right)$ followed by selfing have led to successful introgression of Saltol QTL. Foreground selection at each breeding cycle was done using micro-satellite markers RM3412 and AP3206 to confirm Saltol QTL. The precise transfer of Saltol region was established using recombinant selection through flanking markers RM493 and G11a. Finally, 10 Saltol near isogenic lines (NILs) of Pusa44 and eight NILs of Sarjoo52 were successfully developed. These NILs $\left(\mathrm{BC}_{3} \mathrm{~F}_{4}\right)$ were evaluated for seedling stage salinity under hydroponic system. The NILs PU99, PU176, PU200, PU215, PU229, PU240, PU241, PU244, PU252, PU263 of Pusa44 and SAR17, SAR23, SAR35, SAR39, SAR77, SAR87, SAR123, SAR136 NILs of Sarjoo52 confirmed tolerance to salinity with low salt injury score of 3 or 5 . Ratio of $\mathrm{Na}^{+} / \mathrm{K}^{+}$content of Saltol NILs ranged from 1.26 to 1.85 in Pusa44 and 1.08 to 1.69 in Sarjoo52. The successfully developed NILs were further phenotyped stringently for morphological traits to estimate Phenotypic Recovery. Background selection of NILs along with parents was carried out with 50K SNP chip and recovered $94.83-98.38 \%$ in Pusa44 NILs and 94.51 to $98.31 \%$ in Sarjoo52 NILs of recurrent genome. The present study of MAB has accelerated the development of salt tolerant lines in the genetic background of Pusa44 and Sarjoo52. These NILs could be used for commercial cultivation in saline affected area.

Keywords: salinity, sice, Saltol QTL, NILs, seedling stage, marker assisted backcross breeding 


\section{INTRODUCTION}

Rice is an important cereal crop that is widely produced for human consumption. It is staple food crop for half of the world population and in India it is a key component of food security programs. Moreover, India is largest exporter of rice and exported 12.5 million metric tons (Shahbandeh, 2019) which contributes significantly to the Indian economy. However, abiotic stresses critically limit the crop production and causes significant yield losses. Soil salinity is second major abiotic threat to rice production after drought. Soil salinity is expected to increase globally due to climate change and conventional irrigation practices. More than 800 million hectares of world's land area is salt affected which constitutes more than $6 \%$ of world land area (FAO, 2014). In India salt affected land accounts for 6.73 million hectares which is expected to increase to 16.2 million hectares by 2050 (CSSRI Vision-2050, 2015; Singh, 2018). Salinity could also be attributed to rising sea level which is bringing saline water to inlands and exposing rice growing areas to saline conditions. Due to salinity most of the rice suited areas are left uncultivated or rice grown under these areas has very less yield/hectare compared to national average yield. Rice is considered salt sensitive crop and it is mostly affected at seedling and reproductive stage of its life cycle (Mass and Hoffman, 1977; Zeng et al., 2001; Singh et al., 2007; Tiwari et al., 2015; Krishnamurthy et al., 2016a). Salinity exposure leads to immediate effect which is manifested in few days to some long term affects which occurs after several days to week from initial exposure to salt (Roy et al., 2014; Krishnamurthy et al., 2016c). Upon initial exposure to salinity, plants stomata closes due to change in water potential which leads to inhibition of shoot elongation. This phenomenon is salt accumulation independent effect and was termed osmotic phase in rice plant by Munns and Tester (2008). Long term exposure to salinity was termed ionic phase which is characterized by $\mathrm{Na}^{+}$accumulation and premature senescence of older leaves (Singh et al., 2014; Reddy et al., 2017).

The salinity tolerance plays a crucial role in rice productivity (Momayezi et al., 2009; Tack et al., 2015). Salinity tolerance in rice is a multifactorial trait highly influenced by environment. Genotype and environmental interaction play an important role for salinity tolerance (Krishnamurthy et al., 2016b; Krishnamurthy et al., 2016d; Krishnamurthy et al., 2017). At seedling stage, salinity leads to poor establishment of rice, diminished root/shoot length, leaf size reduction which leads to early plant death (Zeng and Shannon, 2000; Krishnamurthy et al., 2016c). At reproductive stage, salinity tends to reduce the yield by affecting several yield contributing factors (Khatun et al., 1995; Grattan et al., 2002; Singh et al., 2004; Kumar et al., 2015; Krishnamurthy et al., 2015b). Therefore seedling stage salinity tolerance is very important for early plant establishment under saline stress which could help the plant to achieve good vegetative growth later (Babu et al., 2017a). Rice plant has several mechanisms to tolerate high salt concentration; these mechanisms are ion exclusion, osmotic tolerance and tissue tolerance (Munns and Tester, 2008; Roy et al., 2014). Ion exclusion works at root level to prevent the excess accumulation of $\mathrm{Na}^{+}$and $\mathrm{Cl}^{-}$in leaves (Yeo et al., 1990). Osmotic tolerance involves the ability of rice plant to tolerate the drought aspect of salinity by maintaining leaf expansion and stomatal conductance (Rajendran et al., 2009). Tissue tolerance involves sequestration of $\mathrm{Na}^{+}$in the vacuole, enzymes production that catalyze detoxification of reactive oxygen species (ROS) and synthesis of compatible solutes that helps in maintaining positive water potential. There are some traditional landraces like Pokkali, Nona Bokra and Kalaratta in their natural saline habitat exhibits one of these mechanisms and are highly adaptable to these conditions. However, regardless of their ability to survive salinity, these landraces cannot be adopted in commercial production due to their poor quality of seed and less yield. But these genotypes have proved to be an excellent source of salt tolerance gene that could be used to develop salt tolerant varieties (Ravikiran et al., 2018). An important seedling stage salinity tolerant variety FL478 was developed using a high salt tolerant landrace Pokkali. Later, the RILs developed from the parents (Pokkali and IR29) helped in discovery of major QTL Saltol on chromosome 1 (Bonilla et al., 2002). This QTL explained phenotypic variation of $43 \%$ for seedling stage shoot $\mathrm{Na}^{+/} \mathrm{K}^{+}$homoeostasis and express the tolerance at seedling stage in rice. Salinity tolerance at seedling stage is important to establishment of crop at the early stage which is pre requisite for higher grain yield. The salinity tolerance at seedling stage is important in rice where cultivating ecology is coastal area. In coastal salinity is one of the main important stresses at seedling stage. Salinity tolerant at seedling stage is also important where practicing of Direct Seeded Rice (DSR) at salt affected areas.

To counter the damaging effects of salinity on rice production new improved salt tolerant varieties are being developed through conventional breeding method (Krishnamurthy et al., 2019a; Krishnamurthy et al., 2019b; Krishnamurthy et al., 2019c) and also through marker assisted breeding (Singh et al., 2016; Babu et al., 2017b; Geetha et al., 2017; Singh et al., 2018; Bhandari et al., 2019). The conventional method of breeding however is time consuming and more labour intensive (Salvi and Tuberosa, 2005). But MAB on the other hand is more precise and faster method for introgression of useful genes. MAB allows selection at each breeding cycle to validate precise transfer of gene and it also allows limiting the donor region, therefore, avoiding any linkage drag (Singh et al 2016). Finally, the recovery of developed lines can be calculated to mark the high recurrent parental genome recovery (RPG). The DUS (distinctness, uniformity, and stability) testing of NILs along with parents helps to know the recovery of recurrent parental traits along with 50K SNP genotyping (Mani et al., 2015; Singh et al., 2015). Haplotype of Saltol QTL in rice helps to identify the novel salt tolerant genotypes and are helpful in molecular breeding programs to enhance the salinity tolerance in rice (Ali et al., 2013; Babu et al., 2014; Krishnamurthy et al., 2014; Krishnamurthy et al., 2015a; Choudary et al., 2016; Ravikiran et al., 2018).

Marker assisted breeding in rice was successful in developing new improved salt tolerance line in rice (Linh et al., 2012; Luu et al., 2012; Usatov et al., 2015; Singh et al., 2016; Babu et al., 2017b; Singh et al., 2018; Bhandari et al., 2019). Molecular 
markers based technologies helped in mapping of salt tolerant genes on rice chromosomes and few Saltol linked marker like RM3412, AP3206, RM8094, RM493, RM10793 have been identified for marker assisted breeding and screening (Ismail et al., 2007; Thomson et al., 2010). Rice mega varieties namely, Pusa44 and Sarjoo52 are the most popular varieties in the North Western region of India where the green revolution was initiated in rice. These mega rice varieties are high yield varieties under non saline stress situation whereas, highly sensitive to salinity stress at seedling stage. Therefore, the markers assisted breeding (MAB) breeding was employed for introgression of Saltol QTL into these rice varieties to enhance their salinity tolerance.

\section{MATERIALS AND METHODS}

\section{Plant Material}

In the present investigation two high yielding salt sensitive mega varieties of rice Pusa44 and Sarjoo 52 used as recurrent parents to introgress Saltol QTL,from FL478, a seedling stage salinity tolerant variety was used as donor parent. Both Pusa44 and Sarjoo52 cultivars were selected as recipient parents because of their good agronomic characters and suitability in rice growing areas (Mandal et al., 2018). Parents were evaluated for salt tolerance at $8.0 \mathrm{dSm}^{-1}$ in hydroponics and it was found that both Pusa44 and Sarjoo52 were highly susceptible to salinity, FL478 withstands salt very efficiently with very less visual salt injury symptoms (Figure 1). The crosses between recurrent and donor parents were made at Indian Council of Agriculture Research-Central Soil Salinity Research Institute (ICAR-CSSRI) (29 $\left.42^{\prime} 31.13^{\prime \prime}\right)$ ( $\left.76^{\circ} 57^{\prime} 2.13^{\prime \prime}\right)$, Karnal and advanced during Kharif (June-September) season in field and summer (March to May) off-season in glass house conditions from 2010 to 2018.

\section{Molecular Analysis}

Genomic DNA was isolated from rice seedlings using modified Cetyl Trimethyl Ammonium Bromide (CTAB) method (Zheng et al., 1995). The DNA concentration was diluted to $30 \mathrm{ng}^{-1} \mathrm{l}^{-1}$ by UV-vis spectrophotometer (NanoDrop 2000c, Thermo Scientific Products, Wilmington, USA). PCR reactions were carried out on Biometra TGradient Thermocycler (Imperial Life Science (P) Limited, Gurgaon, India). Polymerase chain reaction (PCR) based amplification of target genomic region was done using selected markers in a $10 \mu \mathrm{l}$ reaction mixture containing 30-50 ng of genomic DNA, 10 pmol each of both forward and reverse primers (Sigma Aldrich, Bangalore, India), $0.2 \mathrm{mM}$ dNTPs, 1.5 $\mathrm{mM}$ of $\mathrm{MgCl}_{2}$ and $1.0 \mathrm{U}$ of Taq polymerase (Merck Specialities Private Limited, Mumbai, India). The PCR was run for 35 cycles with initial denaturation for $5 \mathrm{~min}$ at $95^{\circ} \mathrm{C}$, followed by 35 cycles of $30 \mathrm{~s}$ of denaturation at $95{ }^{\circ} \mathrm{C}, 30 \mathrm{~s}$ annealing at $55{ }^{\circ} \mathrm{C}$ and extension for $1 \mathrm{~min}$ at $72{ }^{\circ} \mathrm{C}$. After completion of 35 cycles, final extension at $72{ }^{\circ} \mathrm{C}$ for $7 \mathrm{~min}$ and kept at $4{ }^{\circ} \mathrm{C}$ for cool down. The amplified product was mixed with tracking dye and resolved in gel electrophoresis (CBS Scientific, Thermo Scientific Products, Wilmington, USA) on 3\% agarose gel (MP Biomedicals, LLC, Mumbai, India) in $1 \times$ TBE buffer along with DNA ladder (Thermo Scientific, Wilmington, USA). The gel was scanned in gel documentation system (FluorChem HD2 system, USA) and polymorphic bands were scored for further analysis. Foreground microsatellite markers RM3412 and AP3206 which tightly linked to Saltol QTL (Thompson et al., 2010; Babu et al., 2014), while recombinant markers RM493 and G11A flanked to Saltol QTL (Linh et al., 2012) are employed during foreground and recombinant selection programme. 50K SNP genotyping (Singh et al., 2015) was used to confirm the retaining of maximum desirable genome of recurrent parents in selected salt tolerant NILs.

\section{Breeding Strategy}

The parents were initially screened for three Saltol markers namely, RM3412, AP3206 and RM10793 (Thomson et al., 2010; Babu et al., 2016). Out of which two markers (RM3412 and AP3206) were found to be polymorphic between recurrent and donor parents. These microsatellite markers (RM3412 and AP3206) were used for foreground selection, while flanking markers RM493 and G11A were used for recombinant selection to minimize the donor segment (Table 1). The present study was carried out from 2010 to 2018, donor parent FL478 was crossed with Pusa44 and Sarjoo52 during Kharif (June-September) 2010. The hybridity of $\mathrm{F}_{1} \mathrm{~s}$ was confirmed using Saltol-linked SSR marker RM3412 and AP3206 as part of foreground selection. The confirmed $\mathrm{F}_{1} \mathrm{~s}$ were back crossed to their respective recurrent parent to generate $\mathrm{BC}_{1} \mathrm{~F}_{1}$ seeds. The $\mathrm{BC}_{1} \mathrm{~F}_{1}$ population was subjected to screening for heterozygous
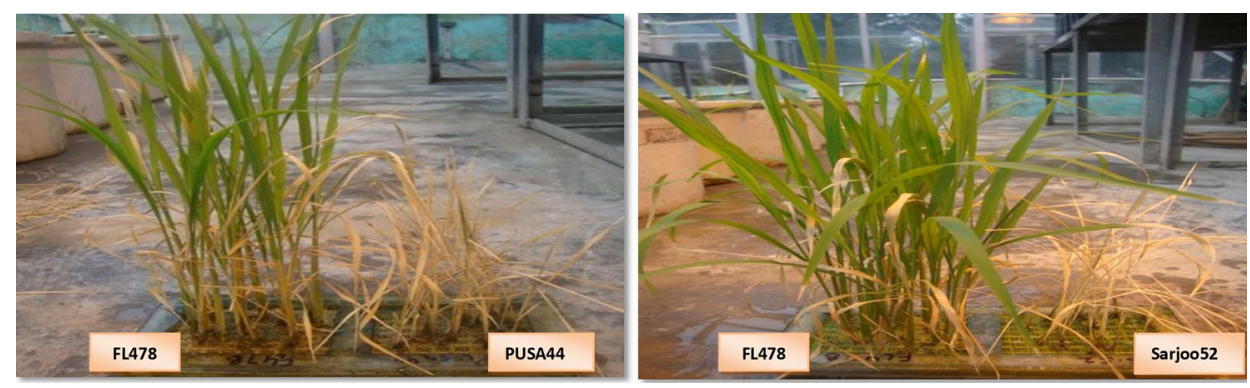

FIGURE 1 | Seedling stage salinity screening of FL478, Sarjoo52 and Pusa44. 
TABLE 1 | List of Saltol SSR markers, forward and reverse sequences used for foreground and recombinant selection in development of Saltol NILs of Pusa44 and Sajoo502.

\begin{tabular}{|c|c|c|c|c|c|}
\hline Sr. No. & Markers & Position (mb) & Forward primer & Reverse primer & Remarks \\
\hline 1 & G11A & 10.24 & AGCTGGTAGGAAGGCTGAAAG & TGCCAGGCAGCTCAGTAGAAG & Recombinant marker \\
\hline 2 & AP3206 & 11.23 & TTCTCATCGCACCATCTCTG & CGACGAGGAGAGGAAGAAG & Foreground marker \\
\hline 3 & RM3412 & 11.58 & AAAGCAGGTITCCTCCTCC & CCCATGTGCAATGTGTCTTC & Foreground marker \\
\hline 4 & RM493 & 12.28 & GTACGTAAACGCGGAAGGTGACG & CGACGTACGAGATGCCGATCC & Recombinant marker \\
\hline
\end{tabular}

Saltol region and recombinant selection; the selected plants from $\mathrm{BC}_{1} \mathrm{~F}_{1}$ populations were advanced to $\mathrm{BC}_{2} \mathrm{~F}_{1}$. The breeding cycle was repeated until $\mathrm{BC}_{3} \mathrm{~F}_{1}$ with careful marker assisted foreground and recombination selection of progenie. At $\mathrm{BC}_{3} \mathrm{~F}_{1}$ plants exhibiting homozygosity for recombinant marker RM493 and G11A were selected from both the populations (Pusa44 and Sarjoo52) and advanced to $\mathrm{BC}_{3} \mathrm{~F}_{2}$ by selfing. In the $\mathrm{BC}_{3} \mathrm{~F}_{2}$ generation, the individual plants showing homozygygosity for Saltol QTL were selected and finally advanced to $\mathrm{BC}_{3} \mathrm{~F}_{4}$.

\section{Screening for Seedling Stage Salinity Tolerance}

The developed NILs of Pusa44 and Sarjoo52 which were homozygous for Saltol QTLs were screened using hydroponics for seedling stage salinity tolerance along with respective parents under controlled glass house conditions at ICAR-CSSRI, Karnal, India, with $29-35^{\circ} \mathrm{C}$ day $/ 21^{\circ} \mathrm{C}$ night temperature. Relative humidity was kept at $30-40 \%$ and photoperiod of $13 \mathrm{~h}$. The $200 \mathrm{~L}$ nutrient tanks were filled with Yoshida nutrient solution (Yoshida et al., 1976) and seedlings were established on floating grids. The whole screening material was divided in to two sets using three replications in each set, one set for control (nonstress) environment and other set for saline treatment. The seeds were sown in hydroponics on the floating grid using normal water for first three days to germinate, after germination plants along with floating grids were transferred to nutrient medium. The solution was replaced once in a week and $\mathrm{pH}$ was maintained at 4.5-5.0 (IRRI, 2013). After the 14th day of sowing, imposed the saline stress through addition of measured quantity of salt (Sodium Chloride $(\mathrm{NaCl})$ ) to nutrient solution and maintained salinity stress level of EC $\sim 8.0 \mathrm{dSm}^{-1}$. Under microplot screening, the seeds of NILs along with parents were allowed to germinate in the soils. Saline water $\left(\mathrm{EC} \sim 8.0 \mathrm{dSm}^{-1}\right.$ ) was irrigated to the soils in microplot for desired salinity stress level $\left(\mathrm{EC} \sim 8.0 \mathrm{dSm}^{-1}\right.$ ). After stringent phenotypic screening of developed NILs under salt stress conditions, the NILs from both populations exhibited tolerance and moderate tolerance were selected and genotyped for background selection using 50K SNP chip. The 50K SNP chip included 50,051 SNPs from 18,980 different genes covering all 12 chromosomes in rice, including 3,710 single-copy (SC) genes conserved between wheat and rice, 14,959 SC genes unique to rice, 194 agronomically important cloned rice genes and 117 multi-copy rice genes. The $50 \mathrm{~K}$ SNP chip used in rice Germplasm characterisation, association mapping, background selection and evolutionary studies as it is efficient and reliable tool (Singh et al., 2015). SNP genotyping helped to confirm the maximum background recovery of desirable recurrent parental genome in the selected NILs at molecular level.

\section{Measurement of Morphological and Physiological Traits}

Phenotyping of NILs along with parents was carried out in randomized complete block design (RCBD) three replications in hydroponics and micro plot during Kharif (June-September) 2015 and 2016, respectively. To evaluate the salinity tolerance of Saltol NILs (Pusa44 and Sarjoo52) 5 traits were recorded namely salt injury score, root length $(\mathrm{cm})$, shoot length $(\mathrm{cm}), \mathrm{Na}^{+}$and $\mathrm{K}^{+}$ concentration $\left(\mathrm{mM} \mathrm{g} \mathrm{dw}{ }^{-1}\right)$ and $\mathrm{Na}^{+} / \mathrm{K}^{+}$. Shoot length was measured from the base of the plant to the tip of longest leaf and root length was measured from the base of the plant to the tip of longest root. For seedling score, the seedlings after 14 days exposure to salt stress were scored as per standard evaluation system (SES) score for rice (IRRI, 2013). The salt injury score 1 was treated as highly tolerant, 3 was tolerant, 5 was moderately tolerant, 7 was susceptible and 9 was highly susceptible. The concentration of $\mathrm{Na}^{+}$and $\mathrm{K}^{+}$ions of plant samples were estimated from di-acid digestion $\left(\mathrm{HNO}_{3}: \mathrm{HClO}_{4} 3: 1\right)$ of samples using atomic absorption spectroscopy (AAS-Zeenit 700P, Analytik Jena, Germany) as per the protocol of Miller and Rutzke 2003.

\section{Distinctive, Uniformity and Stability (DUS)- Based Characterization of NILs}

The NILs of Pusa44 and Sarjoo52 were evaluated for distinctness, uniformity and stability (DUS) characters along with recurrent parents to find the percent similarity (Mondal et al., 2014; Mani et al., 2015). DUS testing is a mode of determining whether a newly bred NILs differs from recurrent parents within the same species (the Distinctness), whether the traits used to establish Distinctness are expressed uniformly (the Uniformity) and that these traits do not change over subsequent generations (the Stability). The Saltol introgressed NILs along with their parents were transplanted from nursery to field at spacing $20 \mathrm{~cm} \times 15 \mathrm{~cm}$ in augmented design experiment during Kharif (JuneSeptember) season of 2016, 2017 and 2018 at the research farm of ICAR-CSSRI, Karnal. The crops were raised as per standard agronomic package of practice and data were recorded at the different stages and characters of NILs were compared with that of recurrent parent (Supplementary Table 1). Similarity percentage of NILs towards the recurrent parent was calculated. 


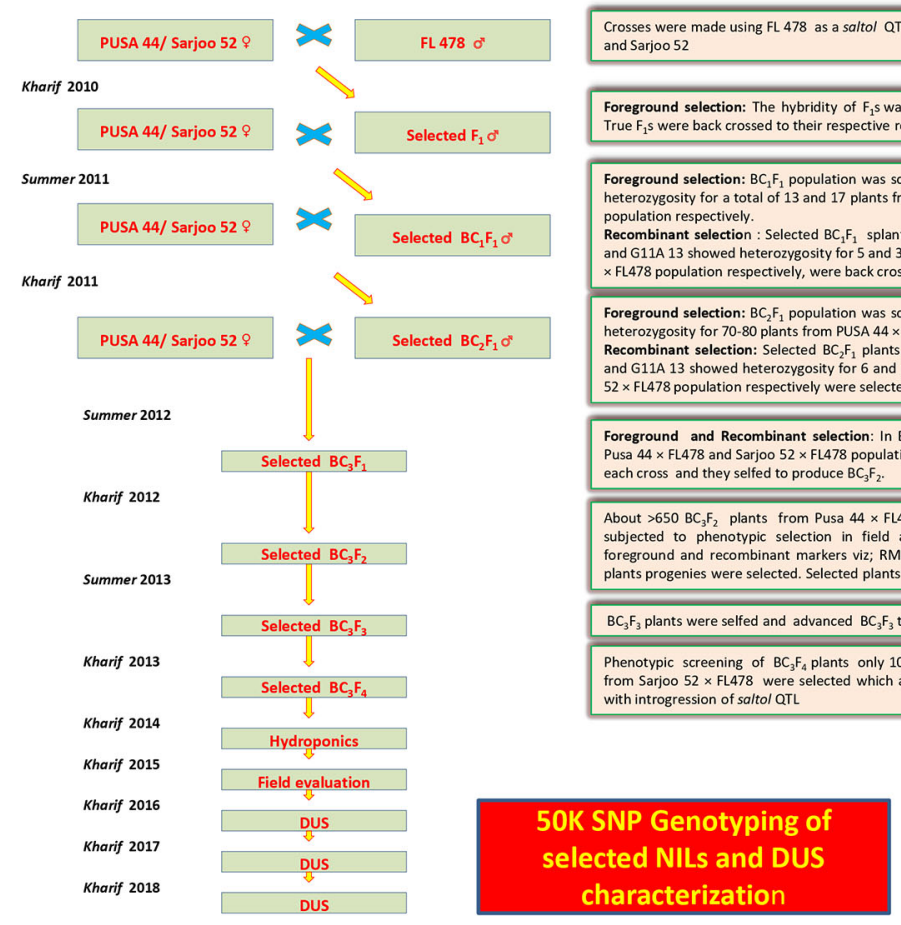

FIGURE 2 | Flowchart for breeding scheme used in marker assisted breeding for successful introgresion of Saltol locus from donor parent to elite breeding lines of Pusa44 and Sarjoo52.

\section{RESULTS}

\section{Development of NILs by Marker-Assisted Back Cross Selection}

The present study leads to the development of Saltol NILs of Pusa44 and Sarjoo52 through Marker Assisted Backcross Breeding (MABB) scheme (Figure 2). Out of Saltol linked markers, there were four markers which were polymorphic between the parents (FL478, Pusa44 and Sarjoo52) two of them used for foreground selection and other two used for recombination selection. Crosses were made during the cropping season using staggered sowing to match the flowering time and $250 \mathrm{~F}_{1}$ seeds were harvested from cross Pusa44 $\times$ FL478 and $150 \mathrm{~F}_{1}$ seeds were harvested from Sarjoo52 $\times$ FL478 cross. The true hybridity of $F_{1}$ is confirmed by employing Saltol linked markers RM3412 and AP3206. The true $\mathrm{F}_{1}$ s were selected from both the population and subjected to backcrossing with respective recurrent parents. A total of 407 $\mathrm{BC}_{1} \mathrm{~F}_{1}$ seeds were harvested from Pusa44 $\times \mathrm{F}_{1}$ cross and 938 $\mathrm{BC}_{1} \mathrm{~F}_{1}$ seeds were harvested from Sarjoo52 $\times \mathrm{F}_{1}$ cross. Foreground screening of $\mathrm{BC}_{1} \mathrm{~F}_{1}$ population with markers RM3412 and AP3206 showed heterozygosity in $13 \mathrm{BC}_{1} \mathrm{~F}_{1}$ plants of Pusa44 back cross progenies and $17 \mathrm{BC}_{1} \mathrm{~F}_{1}$ plants in Sarjoo52 back cross progenies. The recombinant selection was employed using recombinant markers RM493 and G11A to limit the donor region beyond Saltol region, thereby selected plants were further reduced to five and three $\mathrm{BC}_{1} \mathrm{~F}_{1}$ plants, respectively. The selected plants were backcrossed to their recurrent parent and produced $465 \mathrm{BC}_{2} \mathrm{~F}_{1}$ seeds in Pusa44 and $424 \mathrm{BC}_{2} \mathrm{~F}_{1}$ seeds in Sarjoo52. The $\mathrm{BC}_{2} \mathrm{~F}_{1}$ population was subjected to foreground and recombinant selection and six desired plants from Pusa44 and 11 desired plants from Sarjoo52 were acquired. The selected plants of $\mathrm{BC}_{2} \mathrm{~F}_{1}$ were further backcrossed in order to increase the proportion of recurrent parental genome and produced $\mathrm{BC}_{3} \mathrm{~F}_{1}$ seeds. A total of 725 $\mathrm{BC}_{3} \mathrm{~F}_{1}$ seeds from Pusa44 and 850 seeds from Sarjoo52 were harvested. The $\mathrm{BC}_{3} \mathrm{~F}_{1}$ seeds were sown and later plants were screened for desired locus and we got two desirable plants from Pusa44 cross and two desirable plants from Sarjoo52 cross. We selected plants with homozygous for recombinant markers RM493 and G11A for recurrent parent and heterozygous for target Saltol QTL marker RM3412 and AP3206. These plants were self-fertilized to produce $\mathrm{BC}_{3} \mathrm{~F}_{2}$ seeds. Seeds of selected $\mathrm{BC}_{3} \mathrm{~F}_{2}$ plants along with parents were sown in field. About 675 plants from Pusa44 and 705 plants from Sarjoo52 were screened for foreground and recombinant selection with markers viz; RM3412, AP3206 RM493 and G11A and 50 plants from Pusa44 and 62 plants from Sarjoo 52 were found desirable. Finally, $20 \mathrm{BC}_{3} \mathrm{~F}_{2}$ plants from PUSA 44 and $25 \mathrm{BC}_{3} \mathrm{~F}_{2}$ plants from Sarjoo 52 were selected. Selected plants were self-fertilized to produce $\mathrm{BC}_{3} \mathrm{~F}_{3}$ seeds and advanced to $\mathrm{BC}_{3} \mathrm{~F}_{4}$. At last a total of 10 desired NILs of Pusa44 and eight NILs Sarjoo52 of were found completely homozygous for Saltol linked marker RM3412 and AP3206 and recombinant marker RM493 and G11A (Figures 3 and 4). Finally 10 NILs from Pusa44 and 8 NILs from Sarjoo52 were selected based on stringent phenotyping screening (Table 2) and analysis of RPG recovery using $50 \mathrm{~K}$ SNP chip. NILs were selected based on the performance in non-saline and saline stress conditions for agro- 


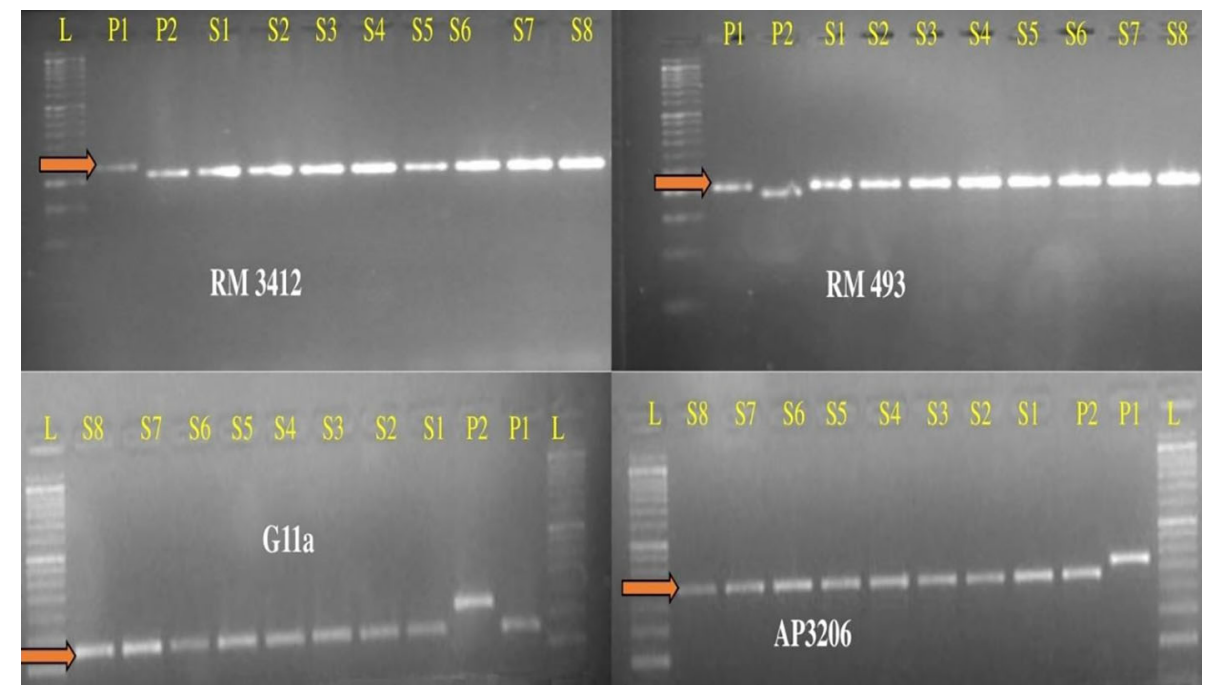

FIGURE 3 | Gel images of $\mathrm{BC}_{3} \mathrm{~F}_{4}$ NILs of Pusa44 based on foreground and recombinant marker screening. L-50bp Ladder, K1-Pusa44, K2-FL478, P1-PU99, P2-PU176, P3-PU200, P4-PU215, P5-PU229, P6-PU240, P7-PU241, P8-PU244, P9-PU252 and P10-PU263.

morphological traits. We selected NILs those were similar to recurrent parent for agro-morphological traits and similar to donor parent for salinity tolerance (salt injury score). Sarjoo52 NILs have recovered $94.51-98.31 \%$ and Pusa44 NILs have recovered $94.83-98.38 \%$ of parental genome, indicating high RPG recovery.

\section{Performance of NILs for Morphological Traits at Seedling Stage in Saline Stress}

The NILs along with their respective parents were evaluated for seedling stage salinity tolerance in hydroponics and microplots $(6 \mathrm{~m} \times 3 \mathrm{~m})$. Combined analyses of variances for developed NILs were computed by comparing the NILs $\times$ location interactions for each character and were combined for further analyses. The analysis of variance showed significant variation among developed NILs of both populations in the tested environments (Tables 3 and 4). Ten NILs of Pusa44 $\times$ FL478 and eight NILs of Sarjoo52 $\times$ FL478 were screened under saline conditions (E.C. $\sim 8.0 \mathrm{dSm}^{-1}$ ). Under salt stress condition, recurrent parent Pusa44 exhibited highly susceptible (scored 8-9) reaction, and Sarjoo52 showed susceptible (scored 7-8). On the other hand donor parent FL478 has performed well and exhibited tolerant reaction (scored 3) under salt stress conditions. Pusa44 NILs namely, PU241 and PU252 were found as tolerant lines with salt

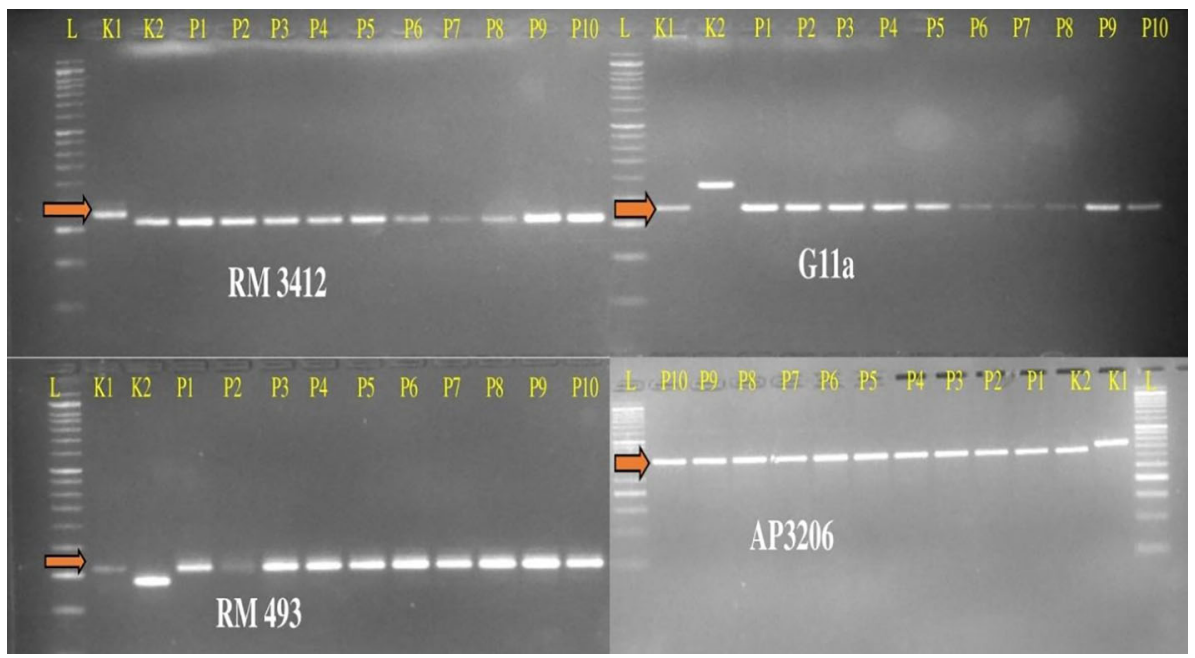

FIGURE 4 | Gel images of $\mathrm{BC}_{3} \mathrm{~F}_{4}$ NILS of Sarjoo52 based on foreground and recombinant marker screening. L-50bp Ladder, P1-Sarjoo52, P2-FL478, S1-SAR17, S2-SAR23, S3-SAR35, S4-SAR56, S5-SAR77, S6-SAR87, S7-SAR123, and S8-SAR136. 
TABLE 2 | Number of seed produced and desired plant through backcross selection of plants based on molecular and phenotypic screening in development of Saltol NILs of Pusa44 and Sajoo52.

\begin{tabular}{|c|c|c|c|c|}
\hline \multirow[t]{2}{*}{ Generation } & \multicolumn{2}{|c|}{ Pusa44 } & \multicolumn{2}{|c|}{ Sarjoo52 } \\
\hline & Total number of seeds produces & No. of desired plant & Total number of seeds produces & No. of desired plant \\
\hline F1 & 300 & 250 & 183 & 150 \\
\hline $\mathrm{BC} 1 \mathrm{~F} 1$ & 407 & 5 & 938 & 3 \\
\hline $\mathrm{BC} 2 \mathrm{~F} 1$ & 465 & 6 & 424 & 11 \\
\hline BC3F1 & 725 & 2 & 850 & 2 \\
\hline BC3F2 & 675 & 20 & 700 & 25 \\
\hline BC3F3 & 20 & 20 & 33 & 33 \\
\hline $\mathrm{BC3F4}$ & 10 & 10 & 8 & 8 \\
\hline
\end{tabular}

injury score of 3 and PU99, PU176, PU200, PU215, PU229, PU240, PU244, PU263 showed moderate salt tolerance with salt injury score 5 in both hydroponics and microplot condition (Table 5). Similarly, Sarjoo52 NILs namely, SAR39, SAR23, SAR136 and SAR17 were found as tolerant lines with salt injury score of 3 while, NILs SAR87, SAR122, SAR35 and SAR77 showed moderate salt tolerance with salt injury score of 5 (Table 6). The average shoot and root length in NILs of Pusa44 were skewed towards the Pusa44 parents but less than FL478. Similarly, average root and shoot length among Sarjoo52 NILs was on par with of Sarjoo52.

\section{Performance of NILs for Physiological Traits at Seedling Stage in Saline Stress}

Significant variation in $\mathrm{Na}^{+}$and $\mathrm{K}^{+}$content under salt stress condition among parents and their respective NILs was found during the physiological analysis of dried plant samples. $\mathrm{Na}^{+}$ content in plant samples of Pusa44 $(31.30 \mathrm{mM} / \mathrm{g}$ of dry weight) was much higher than that of FL478 (14.15 mM/g of dry weight) under saline stress, which inherited the character from one of its parent Pokalli to exclude $\mathrm{Na}^{+}$from its transpirational stream. On the other hand $\mathrm{K}^{+}$content in FL478 was almost similar to that of Pusa44. But the $\mathrm{Na}^{+} / \mathrm{K}^{+}(1.29)$ ratio in FL478 was almost half to $\mathrm{Na}^{+} / \mathrm{K}^{+}$ratio of Pusa44 (2.45) which could be attributed to low $\mathrm{Na}^{+}$content in FL478. Among the Pusa44 NILs, the cationic $\left(\mathrm{Na}^{+}\right)$content was ranged from 13.95 to $27.9 \mathrm{mM} / \mathrm{g}$ of dry weight. All the Pusa44 NILs exhibited lesser $\mathrm{Na}^{+}$concentration than recurrent parent and whereas, except PU263 $(13.95 \mathrm{mM} / \mathrm{g}$ of dry weight) all NILs having more $\mathrm{Na}^{+}$concentration than donor parent FL478. Similarly, potassium concentration of all the NILs was higher than both the parents except the lines PU263 (9.75 mM/g of dry weight) and PU200 (12.30 mM/g of dry weight). The $\mathrm{Na}^{+} / \mathrm{K}^{+}$ratio was too high in Pusa44 (2.45) parent compared to salt tolerant line FL478 (1.29) and the lowest $\mathrm{Na}^{+} /$ $\mathrm{K}^{+}$ratio was observed in PU229 NILs (1.26), it is lesser than donor parent. In the cross of Sarjoo52 and FL478 again significant variation was found in cationic content of both parents. At EC $\sim 8.0 \mathrm{dSm}^{-1}$ high amount of $\mathrm{Na}^{+}$content in plant samples of Sarjoo52, whereas $\mathrm{K}^{+}$content was almost similar in both parents. Sarjoo52 NILs has comparatively similar $\mathrm{Na}^{+}$content as that of Sarjoo52 but higher than FL478, but the $\mathrm{K}^{+}$content was significantly higher in the NILs as compared to both the parents which leads to low ratio of $\mathrm{Na}^{+}$/ $\mathrm{K}^{+}$. The NIL SAR17 exhibited highest $\mathrm{Na}^{+}$content $(30.60 \mathrm{mM} / \mathrm{g}$ of dry weight) while, NIL SAR136 exhibited highest potassium content (22.25 mM/g of dry weight). Among the Sarjoo52 NILs SAR35 and SAR77 exhibited low $\mathrm{Na}^{+}$and $\mathrm{K}^{+}$content, respectively. All the Sarjoo52 NILs exhibited low $\mathrm{Na}^{+} / \mathrm{K}^{+}$than donor parent FL478 except SAR77 and SAR17. The SAR136 exhibited lowest $\mathrm{Na}^{+} / \mathrm{K}^{+}$of 1.08 . $\mathrm{Na}^{+} / \mathrm{K}^{+}$ratio in high salt tolerant NILs with salt injury score of 3 , ranged from 1.08 to 1.33, whereas NILs with salt injury score of 5 has $\mathrm{Na}^{+} / \mathrm{K}^{+}$in range of $1.23-1.69$.

\section{Recovery of NILs With Respect to Recurrent Parents}

Based on the field evaluation of NILs of both populations $($ Sarjoo52 $\times$ FL478) and $($ Pusa44 $\times$ FL478) it was found that the developed NILs were highly similar to their recurrent parents. On the basis of 50 agro-morphological DUS parameters, the percent recovery in NILs of Sarjoo52 $\times$ FL478 population ranged from 92 to $100 \%$ and in Pusa44 $\times$ FL478 population the percent recovery ranged from 84 to $98 \%$ when compared with respective recurrent parents (Supplementary

TABLE 3 | Combined analysis of variance of different traits in Saltol NILs of Pusa44 under saline stress.

\begin{tabular}{|c|c|c|c|c|c|c|}
\hline \multirow[t]{2}{*}{ Source of Variation } & \multirow[t]{2}{*}{ df } & \multicolumn{5}{|c|}{ Mean sum of squares } \\
\hline & & Salt injury score & Shoot Length & Root Length & $\mathrm{Na}^{+}$Content & $\mathrm{K}^{+}$Content \\
\hline Replication & 2 & 0.001 & 0.72 & 2.47 & 0.082 & 4.347 \\
\hline NILs & 11 & 15.09 & $191.07^{\star \star}$ & $33.307^{\star \star}$ & $148.933^{\star \star}$ & $24.008^{\star \star}$ \\
\hline Location & 1 & $0.001^{\star \star}$ & $460.05^{\star \star}$ & $468.690^{\star \star}$ & $276.908^{\star \star}$ & 0.055 \\
\hline NILs $\times$ Location & 11 & 0.01 & 0.129 & 0.299 & 1.035 & 3.244 \\
\hline Error & 46 & 0.0001 & 0.871 & 2.015 & 3.9376 & 1.7893 \\
\hline Total & 71 & 2.33 & 36.68 & 13.183 & 29.688 & 5.504 \\
\hline
\end{tabular}

**Significant at 0.01 level of probability. 
TABLE 4 | Combined analysis of variance of different traits in Saltol NILs of Sarjoo52 under saline stress.

\begin{tabular}{|c|c|c|c|c|c|c|}
\hline \multirow[t]{2}{*}{ Source of Variation } & \multirow[t]{2}{*}{ df } & \multicolumn{5}{|c|}{ Mean sum of squares } \\
\hline & & Salt injury score & Shoot Length & Root Length & $\mathrm{Na}^{+}$Content & $\mathbf{K}^{+}$Content \\
\hline Replication & 2 & 0.001 & $229.558^{\star \star}$ & $44.720^{\star \star}$ & $20.951^{\star \star}$ & 5.535 \\
\hline NILs & 9 & 11.733 & $120.824^{\star \star}$ & $15.631^{*}$ & $48.824^{\star \star}$ & $35.634^{\star \star}$ \\
\hline Location & 1 & $0.001^{\star \star}$ & 0.030 & $378.424^{\star \star}$ & $360.150^{\star \star}$ & $130.095^{\star \star}$ \\
\hline NILs $\times$ Location & 11 & 0.01 & 8.102 & 3.041 & $25.783^{*}$ & $22.348^{\star \star}$ \\
\hline Error & 38 & 0.001 & 14.021 & 4.516 & 8.944 & 2.358 \\
\hline Total & 59 & 1.789 & 36.48 & 13.686 & 23.957 & 12.757 \\
\hline
\end{tabular}

**Significant at 0.01 level of probability, *Significant at 0.05 level of probability.

Table 1). The target locus of the developed NILs was compared with that of their recurrent parent using micro-satellite markers including foreground and recombinant markers to mark the precise transfer of Saltol QTL (Figures 5 and 6). The parental genome recovery percentage at molecular level was estimated in $\mathrm{BC}_{3} \mathrm{~F}_{4}$ NILs using $50 \mathrm{~K}$ SNP chip. Based on the SNP analysis Sarjoo52 NILs have recovered $94.51-98.31 \%$ and Pusa44 NILs have recovered $94.83-98.38 \%$ of parental genome, indicating high RPG recovery. It confirms that the developed NILs were genotypically and phenotypically similar to the recurrent parents in addition of Saltol QTL from donor parent.

\section{DISCUSSION}

Salinity has been a major concern for rice production as cultivable land is under constant threat of saline due to excess use of irrigation water coupled with poor drainage system. Salinity stress affect rice grain yield from 20 to $100 \%$ depends on the stress level and duration of rice exposed to saline stress (Krishnamurthy et al., 2015a). Fortunately, vast genetic variability in rice in response to soil salinity makes possible to develop saline tolerant rice varieties (Akbar et al., 1972; Krishnamurthy et al., 2016c; Krishnamurthy et al., 2017; Krishnamurthy et al., 2019a; Krishnamurthy et al., 2019b; Krishnamurthy et al., 2019c). Sarjoo52 and Pusa44 are highly preferred rice cultivars among farmers for their high yielding potential under normal field condition. However, increasing soil salinity has forced farmer to minimize the area of these preferred mega varieties under cultivation. Continuous efforts are being made toward developing salt tolerant varieties through conventional breeding method (Krishnamurthy et al., 2019a; Krishnamurthy et al., 2019b; Krishnamurthy et al., 2019c). However, the problem with conventional method of breeding is that the developed progenies acquired unwanted traits due to linkage drag and possible negative effects on yield and grain quality traits of rice (Gregorio et al., 2002; Ismail et al., 2007; Thomson et al., 2010). Many researchers has introgressed the Saltol QTL in to different rice varieties Huyen et al. (2012) in AS996, Babu et al. (2017b) in PB1121, Geetha et al. (2017) in ADT43. Therefore the present effort was made to improve these cultivars using MABB method.

The present study was successful in introgressing Saltol QTL in high yielding varieties (Pusa44, Sarjoo52) and simultaneously restricted any linkage drag using marker assisted breeding approach with careful foreground, recombinant selection and background selection. The halplotype of both recipient parents differs from donor parent FL478 at four markers within Saltol region which

TABLE 5 | Performance of Pusa44 Saltol-introgressed NILs for salinity tolerance at seedling stage under hydroponics and microplot conditions. Recurrent parent genome (RPG) and phenotypic recovery of NILs based on 50K SNP analysis and DUS characterization, respectively.

\begin{tabular}{|c|c|c|c|c|c|c|c|c|c|c|c|c|}
\hline \multirow[t]{2}{*}{ NILs } & \multicolumn{2}{|c|}{$\begin{array}{l}\text { Salt injury } \\
\text { Score }\end{array}$} & \multicolumn{2}{|c|}{$\begin{array}{l}\text { Shoot Length } \\
\text { (cm) }\end{array}$} & \multicolumn{2}{|c|}{$\begin{array}{l}\text { Root Length } \\
\text { (cm) }\end{array}$} & \multicolumn{2}{|c|}{$\begin{array}{c}\mathrm{Na}^{+} \text {Content } \\
\text { (mM/g dry } \\
\text { weight) }\end{array}$} & \multicolumn{2}{|c|}{$\begin{array}{l}\mathrm{K}^{+} \text {Content } \mathrm{mM} / \mathrm{g} \\
\text { dry weight }\end{array}$} & \multirow[t]{2}{*}{ Phenotypic recovery (\%) } & \multirow[t]{2}{*}{ Genotypic genome recovery (\%) } \\
\hline & GH & MP & GH & MP & GH & MP & GH & MP & GH & MP & & \\
\hline PU-215 & 5 & 5 & 24.80 & 19.80 & 11.00 & 6.00 & 19.25 & 23.25 & 15.15 & 13.15 & 94.00 & 98.08 \\
\hline PU-176 & 5 & 5 & 25.85 & 20.85 & 12.50 & 7.50 & 27.95 & 30.95 & 15.10 & 16.60 & 86.00 & 97.13 \\
\hline PU-200 & 5 & 5 & 24.50 & 19.50 & 10.40 & 5.40 & 17.60 & 21.60 & 12.30 & 12.30 & 94.00 & 98.38 \\
\hline PU-240 & 5 & 5 & 22.25 & 17.25 & 10.00 & 5.00 & 22.20 & 26.20 & 12.95 & 14.95 & 88.00 & 97.88 \\
\hline PU-229 & 5 & 5 & 26.35 & 21.35 & 11.50 & 6.50 & 19.80 & 23.80 & 15.75 & 13.75 & 96.00 & 97.86 \\
\hline PU-241 & 3 & 3 & 27.35 & 22.35 & 16.25 & 11.25 & 22.75 & 26.75 & 15.45 & 15.95 & 84.00 & 94.83 \\
\hline PU-263 & 5 & 5 & 23.25 & 18.25 & 7.85 & 2.85 & 13.95 & 17.95 & 9.75 & 10.25 & 98.00 & 98.21 \\
\hline PU-99 & 5 & 5 & 23.15 & 18.15 & 8.25 & 3.25 & 19.05 & 23.05 & 13.10 & 13.10 & 96.00 & 98.10 \\
\hline PU-244 & 5 & 5 & 22.75 & 17.75 & 8.45 & 3.45 & 21.85 & 25.85 & 13.15 & 15.15 & 86.00 & 95.91 \\
\hline PU-252 & 3 & 3 & 23.35 & 18.35 & 10.90 & 5.90 & 19.45 & 23.45 & 13.95 & 13.45 & 96.00 & 96.32 \\
\hline Pusa44 & 9 & 9 & 21.75 & 16.75 & 10.75 & 5.75 & 31.30 & 35.30 & 12.80 & 9.30 & & \\
\hline FL478 & 3 & 3 & 42.45 & 37.45 & 13.25 & 8.25 & 14.15 & 18.15 & 10.95 & 10.95 & & \\
\hline Mean & 4.77 & 4.77 & 25.65 & 20.65 & 10.93 & 5.93 & 20.78 & 24.69 & 13.36 & 13.24 & & \\
\hline SEM & 0.45 & 0.45 & 1.12 & 1.12 & 0.54 & 0.54 & 1.08 & 1.04 & 0.47 & 0.50 & & \\
\hline CV\% & 29.65 & 29.65 & 21.87 & 26.38 & 23.95 & 22.63 & 25.29 & 20.13 & 17.99 & 17.77 & & \\
\hline
\end{tabular}

$\mathrm{GH}$, Glass house in hydroponic solution; MP, in micro plot condition. 
TABLE 6 | Performance of Sarjoo52 Saltol-introgressed NILs for salinity tolerance at seedling stage under hydroponics and microplot conditions. Recurrent parent genome (RPG) and phenotypic recovery of NILs based on 5OK SNP analysis and DUS characterization, respectively.

\begin{tabular}{|c|c|c|c|c|c|c|c|c|c|c|c|c|}
\hline \multirow[t]{2}{*}{ NILs } & \multicolumn{2}{|c|}{$\begin{array}{l}\text { Salt Injury } \\
\text { Score }\end{array}$} & \multicolumn{2}{|c|}{$\begin{array}{c}\text { Shoot } \\
\text { Length }(\mathrm{cm})\end{array}$} & \multicolumn{2}{|c|}{$\begin{array}{l}\text { Root Length } \\
\text { (cm) }\end{array}$} & \multicolumn{2}{|c|}{$\begin{array}{c}\mathrm{Na}^{+} \text {Content } \\
\text { (mM/g dry } \\
\text { weight) }\end{array}$} & \multicolumn{2}{|c|}{$\begin{array}{l}\mathrm{K}^{+} \text {Content } \\
\text { (mM/g dry } \\
\text { weight) }\end{array}$} & \multirow[t]{2}{*}{ Phenotypic genome recovery (\%) } & \multirow[t]{2}{*}{ Genotypic genome recovery (\%) } \\
\hline & GH & MP & GH & MP & GH & MP & GH & MP & GH & MP & & \\
\hline SAR122 & 5 & 5 & 33.00 & 29.00 & 10.90 & 6.90 & 20.15 & 24.15 & 14.95 & 11.95 & 100.00 & 98.00 \\
\hline SAR77 & 5 & 5 & 31.50 & 27.50 & 12.50 & 8.50 & 22.05 & 26.05 & 13.05 & 13.05 & 92.00 & 97.15 \\
\hline SAR39 & 3 & 3 & 32.00 & 28.00 & 10.25 & 6.25 & 19.80 & 23.80 & 15.85 & 12.85 & 94.00 & 98.14 \\
\hline SAR23 & 3 & 3 & 28.75 & 24.75 & 10.10 & 6.10 & 23.35 & 27.35 & 17.50 & 14.50 & 98.00 & 94.51 \\
\hline SAR136 & 3 & 3 & 34.00 & 30.00 & 10.75 & 6.75 & 23.95 & 27.95 & 18.75 & 15.75 & 96.00 & 97.70 \\
\hline SAR87 & 3 & 3 & 35.60 & 31.60 & 13.50 & 9.50 & 22.10 & 26.10 & 18.80 & 15.80 & 98.00 & 98.31 \\
\hline SAR17 & 5 & 5 & 32.25 & 28.25 & 11.60 & 7.60 & 30.60 & 34.60 & 19.00 & 16.00 & 96.00 & 98.28 \\
\hline SAR35 & 5 & 5 & 32.85 & 28.85 & 12.45 & 8.45 & 17.35 & 21.35 & 14.15 & 11.15 & 98.00 & 97.43 \\
\hline Sarjoo52 & 7 & 7 & 31.75 & 27.75 & 11.10 & 7.10 & 21.90 & 25.90 & 11.20 & 8.20 & & \\
\hline FL478 & 3 & 3 & 46.30 & 42.30 & 16.60 & 12.60 & 15.00 & 19.00 & 10.60 & 10.60 & & \\
\hline Mean & 4.26 & 4.26 & 33.80 & 29.80 & 11.98 & 7.98 & 21.63 & 25.63 & 15.39 & 12.99 & & \\
\hline SEM & 0.44 & 0.44 & 1.08 & 1.08 & 0.47 & 0.47 & 0.96 & 0.96 & 0.76 & 0.67 & & \\
\hline CV\% & 33.29 & 33.29 & 14.29 & 15.82 & 17.45 & 25.22 & 19.92 & 16.36 & 22.08 & 21.71 & & \\
\hline
\end{tabular}

$\mathrm{GH}$, Glass house in hydroponic solution; MP, in microplot condition.

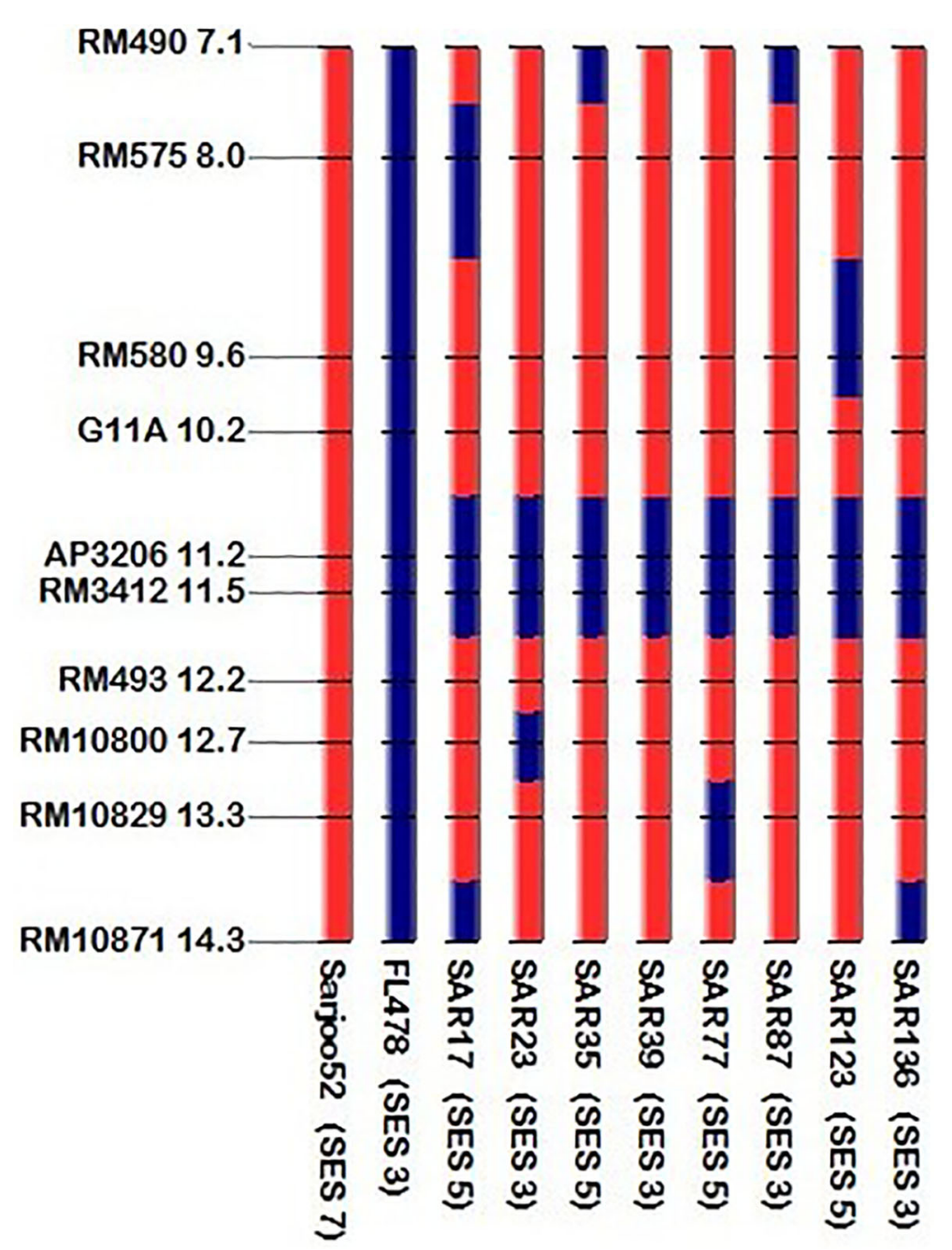

FIGURE 5 | Haplotypic representation at target locus of Saltol introgressed BC3F4 line of Sarjoo52 along with parents. 


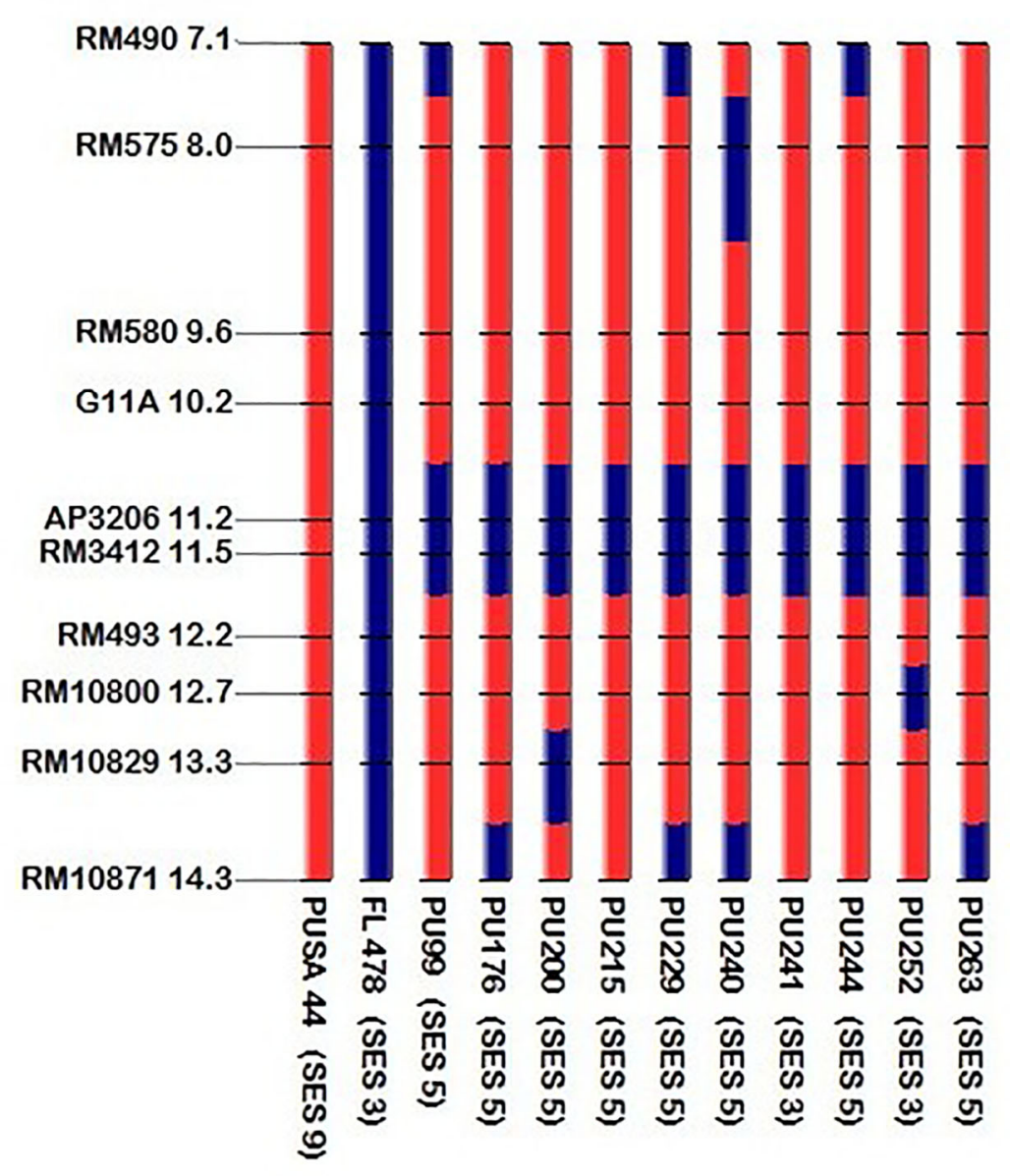

FIGURE 6 | Haplotypic representation at target locus of Saltol introgressed BC3F4 line of Pusa44 along with parents.

includes RM3412, RM493, AP3206 and G11A. RM3412 and AP3206 were recognized as tightly linked Saltol markers while G11A and RM493 were selected as recombinant marker to mark the precise transfer Saltol. The RPG recovery in NILs of both crosses was achieved by three backcrosses with recurrent parents followed by selfing of $\mathrm{BC}_{3} \mathrm{~F}_{1}$ lines for four generations which leads to homozygosity of Saltol allele. Even though the developed $\mathrm{BC}_{3} \mathrm{~F}_{4}$ lines possesses high RPG recovery percentage but still these line has residual donor genome of $1.62-5.51 \%$. In spite this donor region, the impact on the agronomic characters of developed NILs were negligible. In plant breeding principle, three back crosses recovered the genome by $93.75 \%$. However, use of markers helps to enhanced it upto $98.38 \%$. Morphological and physiochemical analysis of plant samples has revealed differential response to salinity among developed NILs. Two $\mathrm{BC}_{3} \mathrm{~F}_{4}$ lines derived from Pusa44 $\times$ FL478 viz., PU241 and PU252 (SES score 3) were found to be more tolerant than other NILs. On the other hand NILs from Sarjoo52 $\times$ FL478 cross designated SAR39, SAR23, SAR136 and SAR87 performed very well under saline condition with salt injury score of three. Even after achieving homozygosity at Saltol region, the plant exhibit different ionic content and differential salinity tolerance with respect to FL478. This response to salinity could be attributed to the complexity of salt tolerance character. The other reason behind this variation could be explained by the fact that Saltol region from donor parent might be affected by the genetic background of recipient parents.

The Saltol QTL comprises multiple genes associated with salt tolerance which includes membrane transporters, signal transducers, transcriptional factors. However, Ren et al. (2005) explained its role in maintaining good $\mathrm{Na}^{+} / \mathrm{K}^{+}$homoeostasis and similar homoeostasis was observed in developed NILs. In Pusa44 NILs the $\mathrm{Na}^{+}$content was as low as that of FL478 while $\mathrm{K}^{+}$ content was higher than FL478. The Pusa44 NILs decreased the $\mathrm{Na}$ content by 2 folds as compared to recurrent parent (Pusa44) and Sarjoo52 NILs decreased by 1.23 folds as compared to its recurrent parent (Sarjoo 52). In Sarjoo52, NILs the $\mathrm{Na}^{+}$content was more inclined toward Sarjoo52 which was significantly higher than FL478. But interestingly the $\mathrm{K}^{+}$content in NILs was much higher than both parents and in NIL SAR136 $\mathrm{K}^{+}$ content was more than double compared to FL478. However, the $\mathrm{Na}^{+} / \mathrm{K}^{+}$ratio was more skewed toward FL478 which explains the salt tolerance characters in theses developed NILs. This indicated that the introgressed region in NILs have significant role in $\mathrm{Na}^{+}$ and $\mathrm{K}^{+}$homoeostasis. Furthermore, DUS (Distinctiveness, Uniformity, Stability) characterization revealed the similarity of 
these NILs with their recurrent parents. The traits used to know the phenotypic differences between NILs and parents thereby find the similarity and differences. In this context we are employed backcross breeding method to improve the Pusa44 and Sarjoo52 mega varieties by marker assisted introgression of QTLs from donor parent FL478. If we employing DUS test to compare NILs and recurrent Parents, as phenotypic differences between NILs and parents is less indicated the more similarity with recurrent parents. The developed NILs will be as similar to the parental lines except for the salt tolerance.

The present study was successful in incorporation of seedling stage salinity tolerant QTLs in two high yielding varieties i.e. Pusa44 and Sarjoo52 through marker assisted breeding. The developed lines from both the recurrent parent acquired salinity tolerance at seedling stage and simultaneously these lines have achieved high recurrent parent genome recovery during field evaluation and background selection. The Saltol NIL's have developed good ionic balance during physiological analysis of rice samples under salt stressed conditions with fair amount of $\mathrm{K}^{+}$ions in plant samples. The developed lines will be further evaluated on multiple locations under target saline environment before they are released for commercial production in farmer's field. The present study has formed a blue chart for future breeding programs aimed for development of salt tolerant varieties highly suitable for salt affected areas.

\section{DATA AVAILABILITY STATEMENT}

All datasets generated for this study are included in the article/ Supplementary Materials.

\section{REFERENCES}

Akbar, M., Yabuno, T., and Nakao, S. (1972). Breeding for Saline-resistant Varieties of Rice: I. Variability for Salt Tolerance among Some Rice Varieties. Jpn. J. Breed. 22, 277-284. doi: 10.1270/jsbbs1951.22.277

Ali, S., Gautam, R. K., Mahajan, R., Krishnamurthy, S. L., Sharma, S. K., Singh, R. K., et al. (2013). Stress indices and selectable traits in SALTOL QTL introgressed rice genotypes for reproductive stage tolerance to Sodicity and salinity stresses. Field Crops Res. 154, 65-73. doi: 10.1016/j.fcr.2013.06.011

Babu, N. N., Vinod, K. K., Gopala, S., Krishnan, P. K., Vanaja, B. T., Krishnamurthy, S. L., et al. (2014). Marker based haplotype diversity of Saltol QTL in relation to seedling stage salinity tolerance in selected genotypes of rice. Indian J. Genet. Pl. Br. 74 (1), 16-25. doi: 10.5958/j.0975-6906.74.1.003

Babu, N. N., Krishnan, S. G., Vinod, K. K., Krishnamurthy, S. L., Singh, V. K., Singh, M. P., et al. (2017a). Marker Aided Incorporation of Saltol, a Major QTL Associated with Seedling Stage Salt Tolerance, into Oryza sativa'Pusa Basmati 1121'. Front. Plant Sci. 8, 41. doi: 10.3389/fpls.2017.00041

Babu, N. N., Vinod, K. K., Krishnamurthy, S. L., Krishnan, S. G., Yadav, A., Bhowmick, P. K., et al. (2017b). Microsatellite based linkage disequilibrium analyses reveal Saltol haplotype fragmentation and identify Novel QTLs for seedling stage salinity tolerance in rice. J. Plant Biochem. Biotechnol. 26 (3), 310-320. doi: 10.1007/s13562-016-0393-3

Bhandari, A., Jayaswal, P., Yadav, N., Singh, R., Singh, Y., Singh, B., et al. (2019). Genomics-assisted backcross breeding for infusing climate resilience in highyielding green revolution varieties of rice. Indian J. Genet. 79 (1), 160-170. doi: 10.31742/IJGPB.79S.1.5

Bonilla, P., Dvorak, J., Mackill, D., Deal, K., and Gregorio, G. (2002). RFLP and SSLP mapping of salinity tolerance genes in chromosome 1

\section{AUTHOR CONTRIBUTIONS}

SK, NS, and PS conceptualized and designed the experiment. SK, $\mathrm{PP}, \mathrm{BL}$, and SR conducted the experiments. AW and BL did the field evaluations. PP, AW, and BL conducted the hydroponics screening of developed NILs. SR and PP isolated the DNA and did molecular screening. NS carried out background marker screening. SK analyzed the data. The manuscript was prepared by SK, AW, and BL. Revision of the manuscript was done by SK, NS, and PS.

\section{FUNDING}

The authors acknowledge the generous funding for the project "From QTL to Variety" (Grant No. BT/PR/14544/AGR/02/745/ 2010) through Department of Biotechnology, Government of India.

\section{ACKNOWLEDGMENTS}

The authors acknowledge the funding from Department of Biotechnology and Director, ICAR-CSSRI, Karnal for providing us infrastructure to conduct the experiment.

\section{SUPPLEMENTARY MATERIAL}

The Supplementary Material for this article can be found online at: https://www.frontiersin.org/articles/10.3389/fpls.2020.00833/ full\#supplementary-material

of rice (Oryza sativa L.) using recombinant inbred lines. Philipp. Agric. Sci. 85, 68-76.

Choudary, A. D., Haritha, G., Sunita, T., Krishanmurthy, S. L., Divya, B., Padmavathi, G. T., et al. (2016). Haplotyping of rice genotypes using SSRs associated with salt tolerance. Rice Sci. 23 (6), 317-325. doi: 10.1016/ j.rsci.2016.05.003

CSSRI Vision 2050 (2015). Director (Karnal, Haryana, India: ICAR-Central Soil Salinity Research Institute).

FAO (2014). Extent of salt affected soils. http://www.fao.org/soils-portal/ soilmanagement/management-of-someproblem-soils/salt-affected-soils/ moreinformation-on-saltaffected- soils/en/

Geetha, S., Vasuki, A., Jagadeesh, S. P., Saraswathi, R., Krishnamurthy, S. L., Manikandan, M. P., et al (2017). Development of sodicity tolerant rice varieties through marker assisted backcross breeding. Electron. J. Plant Breed 8 (4), 1013-1021. doi: 10.5958/0975-928X.2017.00151.X

Grattan, S., Zeng, L., Shannon, M. C., and Roberts, S. (2002). Rice is more sensitive to salinity than previously thought. California Agric. 56, 189-198. doi: 10.3733/ ca.v056n06p189

Gregorio, G. B., Senadhira, D., Mendoza, R. D., Manigbas, N. L., and Roxas and Guerta, C. Q. (2002). Progress in breeding for salinity tolerance and associated abiotic stresses in rice. Field Crop Res. 76, 91-101. doi: 10.1016/S0378-4290(02) 00031-X

Huyen, L., Cuc, L., Ismail, A. M., and Ham, L. (2012). Introgression the Salinity Tolerance QTLs Saltol into AS996, the Elite Rice Variety of Vietnam. Am. J. Plant Sci. 3, 981-987. doi: 10.4236/ajps.2012.37116

IRRI (2013). Standard Evaluation System (SES) for Rice. 3rd ed. (Manila, Philippines: International Rice Research Institute). 
Ismail, A. M., Heuer, S., Thomson, M. J., and Wissuwa, M. (2007). Genetic and genomic approaches to develop rice germplasm for problem soils. Plant Mol. Biol. 65, 547-570. doi: 10.1007/s11103-007-9215-2

Khatun, S., Rizzo, C. A., and Flowers, T. J. (1995). Genotypic variation in the effect of salinity on fertility in rice. Plant Soil. 173 (2), 239-250. doi: 10.1007/ BF00011461

Krishnamurthy, S. L., Sharma, S. K., Kumar, V., Tiwari, S., Batra, V., and Singh, N. K. (2014). Assessment of genetic diversity in rice genotypes for salinity tolerance using Saltol markers of Chromosome 1. Indian J. Genet. Pl. Br. 74 (2), 243-247. doi: 10.5958/0975-6906.2014.00167.9

Krishnamurthy, S. L., Sharma, S. K., Kumar, V., Tiwari, S., and Singh, N. K. (2015a). Analysis of genomic region spanning Saltol using SSR markers in rice genotypes showing differential seedlings stage salt tolerance. J. Plant Biochem. Biotechnol. 25 (3), 331-336. doi: 10.1007/s13562-015-0335-5

Krishnamurthy, S. L., Pundir, P., Singh, Y. P., Sharma, S. K., Sharma, P. C., and Sharma, D. K. (2015b). Yield stability of rice lines for salt tolerance using additive main effects and multiplicative interaction analysis - AMMI. J. Soil Salinity Water Qual. 7, 98-106.

Krishnamurthy, S. L., Gautam, R. K., Sharma, P. C., and Sharma, D. K. (2016a). Effect of different salt stresses on agro-morphological traits and utilization of salt stress indices for reproductive stage salt tolerance in rice. Field Crops Res. 190, 26-33. doi: 10.1016/j.fcr.2016.02.018

Krishnamurthy, S. L., Sharma, P. C., Ravikiran, K. T., Basak, N., Vineeth, T. V., Singh, Y. P., et al. (2016b). G×E Interaction and Stability Analysis for Salinity and Sodicity Tolerance in Rice at Reproductive Stage. J. Soil Salinity Water Qual. 8 (2), 54-64.

Krishnamurthy, S. L., Sharma, P. C., Sharma, S. K., Batra, V., Kumar, V., and Rao, L. V. S. (2016c). Effect of salinity and use of stress indices of morphological and physiological traits at the seedling stage in rice. Indian J. Exp. Biol. 54, 12) 843850.

Krishnamurthy, S. L., Sharma, S. K., Sharma, D. K., Sharma, P. C., Singh, Y. P., Mishra, V. K., et al. (2016d). Analysis of Stability and G×E interaction of Rice Genotypes across Saline and Alkaline Environments in India. Cereal Res. Commun. 44 (2), 349-360. doi: 10.1556/0806.43.2015.055

Krishnamurthy, S. L., C, P., Sharma, D. K., Ravikiran, K. T., Singh, Y. P., Mishra, V. K., et al. (2017). Identification of mega-environments and rice genotypes for general and specific adaptation to saline and alkaline stresses in India. Sci. Rep. 7, 1-14. doi: 10.1038/s41598-017-08532-7

Krishnamurthy, S. L., Sharma, P. C., Singh, Y. P., Gautam, R. K., Singh, R. K., Sharma, D. K., et al. (2019a). Notification of crop varieties and registration of Germplasm: Variety CSR46 (IET 18710). Indian J. Genet. 79 (2), 511-512.

Krishnamurthy, S. L., Sharma, P. C., Gautam, R. K., Singh, R. K., Singh, Y. P., Mishra, V. K., et al. (2019b). Notification of crop varieties and registration of Germplasm: Variety CSR56 (IET 24537). Indian J. Genet. 79 (2), 512-513.

Krishnamurthy, S. L., Sharma, P. C., Gautam, R. K., Singh, R. K., Singh, Y. P., Mishra, V. K., et al. (2019c). Notification of crop varieties and registration of Germplasm: Variety CSR60. Indian J. Genet. 79 (2), 513-514.

Kumar, V., Singh, A., Amitha Mithra, S. V., Krishnamurthy, S. L., Parida, S. K., Jain, S., et al. (2015). Genome-wide association mapping of salinity tolerance in rice (Oryza sativa). DNA Res. 22 (2), 133-145. doi: 10.1093/dnares/dsu046

Linh, L. H., Linh, T. H., Xuan, T. D., Ham, L. H., Ismail, A. M., and Khanh, T. D. (2012). Molecular Breeding to Improve Salt Tolerance of Rice (Oryza sativa L.) in the Red River Delta of Vietnam. Int. J. Plant Gen. (66), 949038 doi: 10.1155/ 2012/949038

Luu, T. N. H., Luu, M. C., Ismail, A. M., and Ham, L. H. (2012). Introgression the Salinity Tolerance QTLs Saltol into AS996, the Elite Rice Variety of Vietnam. Am. J. Plant Sci. 3, 981-987. doi: 10.4236/ajps.2012.37116

Mandal, S., Karmakar, M., and Mondal, S. (2018). Performance of few new paddy different paddy varieties at lateritic soil of West Bengal, India. Int. J. Sci. Env. Tech. 7 ((5)), 1592-1596.

Mani, B. R., Kumar, B. M. D., and Krishnamurthy, S. L. (2015). Genetic variability and diversity of rice land races of South Western India based on morphological traits. Oryza 51 (4), 261-266.

Mass, E. V., and Hoffman, G. J. (1977). 'Crop Salt Tolerance Current Assessment'. J. Irr. Drain. Div.-ASCE 103, 115-134.

Momayezi, M. R., Zaharah, A. R., Hanafi, M. M., and Mohd Razi, I. (2009). Agronomic characteristics and proline accumulation of Iranian rice genotypes at early seedling stage under sodium salts stress. Malays. J. Soil Sci. 13, 59-75.
Mondal, B., Singh, S., and Joshi, D. (2014). DUS characterization of rice (Oryza sativa L.) using morphological descriptors and quality parameters. Outlook Agr. 43, 131-137. doi: 10.5367/oa.2014.0167

Munns, R., and Tester, M. (2008). Mechanism of salinity tolerance. Annu. Rev. Plant Biol. 59, 651-668. doi: 10.1146/annurev.arplant.59.032607.092911

Rajendran, K., Tester, M., and Roy, S. J. (2009). Quantifying the three main components of salinity tolerance in cereals. Plant Cell Environ. 32 (3), 237-249. doi: $10.1111 / j .1365-3040.2008 .01916 . x$

Ravikiran, K. T., Krishnamurthy, S. L., Warraich, A. S., and Sharma, P. C. (2018). Diversity and haplotypes of rice genotypes for seedling stage salinity tolerance analyzed through morpho-physiological and SSR markers. Field Crops Res. 220, 10-18. doi: 10.1016/j.fcr.2017.04.006

Reddy, I. N. B. L., Kim, B. K., Yoon, I. S., Kim, K. H., and Kwon, T. R. (2017). Salt Tolerance in Rice: Focus on Mechanisms and Approaches. Rice Sci. 24(3), 123 144. doi: $10.1016 /$ j.rsci.2016.09.004

Ren, Z. H., Gao, J. P., Li, L. G., Cai, X. L., Huang, W., and Chao, D. Y. (2005). A rice quantitative trait locus for salt tolerance encodes a sodium transporter. Nat. Genet. 37, 1141-1146. doi: 10.1038/ng1643

Roy, S. J., Negrão, S., and Tester, M. (2014). Salt resistant crop plants. Curr. Opin. Biotech. 26, 115-124. doi: 10.1016/j.copbio.2013.12.004

Salvi, S., and Tuberosa, R. (2005). To clone or not to clone plant QTLs: present and future challenges. Trends Plant Sci. 10, 297-304. doi: 10.1016/ j.tplants.2005.04.008

Shahbandeh (2019). Principal rice exporting countries worldwide 2018/2019, https://www.statista.com/statistics/255947/top-rice-exporting-countriesworldwide-2011/ access in 10.12.2019.

Singh, R. K., Mishra, B., and Singh, K. N. (2004). Salt tolerant rice varieties and their role in reclamation programme in Uttar Pradesh. Indian Farming, 6-10.

Singh, R. K., Gregorio, G. B., and Jain, R. K. (2007). QTL mapping for salinity tolerance in rice. Physiol. Mol. Biol. Plants 13, 87-99.

Singh, Y. P., Singh, D., and Krishnamurthy, S. L. (2014). Grouping of Advanced Rice Breeding Lines Based on Grain Yield and Na:K Ratio under Alkaline Conditions. J. Soil Salinity Water Qual. 6 (1), 21-27.

Singh, N., Jayaswal, P. K., Panda, K., Mandal, P., Kumar, V., Singh, B., et al (2015). Single-copy gene based $50 \mathrm{~K}$ SNP chip for genetic studies and molecular breeding in rice. Sci. Rep. 5. doi: 10.1038/srep11600. Article number: 11600.

Singh, R., Singh, Y., Xalaxo, S., Verulkar, S., Yadav, N., Singh, S., et al. (2016). From QTL to variety- Harnessing the benefits of QTLs for drought, flood and salt tolerance in mega rice varieties of India through a multi-institutional network. Plant Sci. 242, 278-287. doi: 10.1016/j.plantsci.2015.08.008

Singh, V. K., Singh, B. D., Kumar, A., Maurya, S., Subbaiyan, G. K., Vinod, K. K., et al. (2018). Marker-Assisted Introgression of Saltol QTL Enhances Seedling Stage Salt Tolerance in the Rice Variety "Pusa Basmati 1". Int. J. Genomics doi: 10.1155/2018/8319879. Article ID 8319879.

Singh, G. (2018). Climate Change and Sustainable Management of Salinity in Agriculture. Res. Med. Eng. Sci. 6 (2). doi: 10.31031/RMES.2018.06.000635

Tack, J., Singh, R. K., Nalley, L. L., Viraktamath, B. C., Krishnamurthy, S. L., Lyman, N., et al. (2015). High vapor pressure deficit drives salt-stress induced rice yield losses in India. Glob. Change Biol. 21, 1668-1678. doi: 10.1111/ gcb. 12803

Thomson, M. J., de Ocampo, M., Egdane, J., Rahman, M. K., Sajise, A. G., Dante, A. L., et al. (2010). Characterizing the Saltol quantitative trait locus for salinity tolerance in rice. Rice 3, 148-160. doi: 10.1007/s12284-010-9053-8

Tiwari, S., Krishnamurthy, S. L., Kumar, V., Singh, B., Rao, A. R., Amitha Mithra, S. V., et al. (2015). Mapping QTLs for Salt Tolerance in Rice (Oryza sativaL.) by Bulked Segregant Analysis of Recombinant Inbred Lines Using 50K SNP Chip. PloS One 11 (4), e0153610. doi: 10.1371/journal.pone.0153610

Usatov, A., Alabushev, A. V., Kostylev, P. I., Azarin, K. V., Makarenko, M. S., and Usatova, O. A. (2015). Introgression the SalTol QTL into the elite rice variety of Russia by marker-assisted selection. Am. J. Plant Sci. 10, 165-169. doi: 10.3844/ ajabssp.2015.165.169

Yeo, A. R., Yeo, M. E., Flowers, S. A., and Flowers, T. J. (1990). Screening of rice (Oryza sativa L.) genotypes for physiological characters contributing to salinity resistance, and their relationship to overall performance. Theor. Appl. Genet. 79, 377-384. doi: 10.1007/BF01186082

Yoshida, S., Forno, D., Cock, J., and Gomez, K. (1976). Routine procedure for growing rice plants in culture solution. Laboratory Manual for Physiological 
Studies of Rice. 3rd ed. (Los Baños, Laguna, Philippines: The International Rice Research Institute), 61-66.

Zeng, L., and Shannon, M. C. (2000). Salinity Effects on Seedling Growth and Yield Components of Rice. Crop Sci. 40, 996-1003. doi: 10.2135/cropsci2000. 404996x

Zeng, L., Shannon, M. C., and Lesch, S. M. (2001). Timing of salinity stress affects rice growth and yield components. Agric. Water Manage. 48, 191-206. doi: 10.1016/S0378-3774(00)00146-3

Zheng, K., Subudhi, P. K., Domingo, J., Magpantay, G., and Huang, N. (1995). Rapid DNA isolation for marker assisted selection in rice breeding. Rice Genet. Newslett. 12, 255-258.
Conflict of Interest: The authors declare that the research was conducted in the absence of any commercial or financial relationships that could be construed as a potential conflict of interest.

Copyright $\odot 2020$ Krishnamurthy, Pundir, Warraich, Rathor, Lokeshkumar, Singh and Sharma. This is an open-access article distributed under the terms of the Creative Commons Attribution License (CC BY). The use, distribution or reproduction in other forums is permitted, provided the original author(s) and the copyright owner(s) are credited and that the original publication in this journal is cited, in accordance with accepted academic practice. No use, distribution or reproduction is permitted which does not comply with these terms. 